\title{
PENYELESAIAN MODEL IMUNOLOGI SELULER PADA TUBERKULOSIS DENGAN METODE EXTENDED RUNGE KUTTA ORDE EMPAT DAN RUNGE KUTTA ORDE EMPAT
}

\author{
Ria Risca Pratiwi, Helmi, Yudhi
}

\section{INTISARI}

\begin{abstract}
Metode Extended Runge Kutta adalah metode perluasan dari metode Runge Kutta. Metode Extended Runge Kutta merupakan salah satu metode numerik yang dapat menyelesaikan permasalahan nilai awal pada persamaan diferensial biasa linear maupun nonlinear dengan tingkat ketelitian yang cukup tinggi. Sehingga menghasilkan nilai galat atau error yang lebih kecil dari metode Runge Kutta. Tujuan penelitian ini untuk menyelesaikan model imunologi seluler pada tuberkulosis dengan metode Extended Runge Kutta orde empat. Model imunologi seluler pada tuberkulosis berbentuk sistem persamaan diferensial biasa nonlinear yang terdiri dari empat variabel tak bebas yaitu dengan nilai awal makrofag tak terinfeksi $\left(M_{U}\right)$ adalah 0.7, makrofag terinfeksi $\left(M_{I}\right)$ adalah 0.2 , bakteri Mtb atau Mycobacterium Tuberculosis (B) adalah 0, dan sel T (T) adalah 0. Dari hasil analisis, diperoleh bahwa nilai solusi dan nilai galat yang diperoleh dari metode Extended Runge Kutta orde empat pada variabel bakteri Mtb (B) lebih kecil dari metode Runge Kutta orde empat.
\end{abstract}

Kata kunci: Runge Kutta, Extended Runge Kutta, Persamaan Diferensial Biasa Nonlinear.

\section{PENDAHULUAN}

Metode Extended Runge Kutta adalah metode perluasan dari metode Runge Kutta. Pada metode Extended Runge Kutta ada penambahan orde derajat $h$, sehingga ada penambahan terhadap fungsi evaluasinya [1]. Ada beberapa penelitian yang membahas metode Extended Runge Kutta, diantaranya Wu dan Jianlin (2006), yang menyelesaikan sistem persamaan diferensial biasa otonom dengan metode Extended Runge Kutta [2]. Setelah itu, Jikantoro, Fauziah, Norazak dan Muhammed (2016) menyelesaikan fungsi turunan untuk persamaan diferensial biasa otonom dan non-otonom dengan metode Extended Runge Kutta [3]. Kemudian Muhammad (2015) yaitu mengkaji metode Extended Runge Kutta dan penerapan metode pada persamaan diferensial biasa [1]. Berdasarkan penelitianpenelitian tersebut, metode Extended Runge Kutta menghasilkan nilai galat yang lebih kecil dari metode Runge Kutta. Sehingga dalam hal ini peneliti menerapkan metode Extended Runge Kutta orde empat dalam menyelesaikan model imunologi seluler pada tuberkulosis. Model imunologi seluler pada tuberkulosis merupakan suatu model yang digunakan untuk mengevaluasi dampak dari respon sel T dan makrofag dalam pengendalian bakteri Mtb (Mycobacterium Tuberculosis) [4]. Model imunologi seluler pada tuberkulosis memiliki empat variabel tak bebas. Keempat variabel tersebut yaitu populasi makrofag tak terinfeksi $\left(M_{U}\right)$, populasi makrofag terinfeksi $\left(M_{I}\right)$, populasi bakteri Mtb $(B)$, dan populasi sel T $(T)$ [4].

Langkah-langkah yang dilakukan dalam penelitian ini yang pertama adalah menentukan nilai awal setiap variabel yaitu populasi makrofag tak terinfeksi $M_{U}(0)=0,7$, makrofag terinfeksi $M_{I}(0)=0,2$, bakteri $\operatorname{Mtb}(B(0))=0$ dan sel $\mathrm{T}(T(0))=0$. Kedua mengidentifikasi nilai parameter serta menentukan iterasi yaitu $i=0$ hingga $i=5000$ dengan waktu $t=0$ hari hingga waktu $t=500$ hari dan ukuran langkah $h$ yang digunakan adalah 0,1. Ketiga, menentukan formulasi turunan model imunologi seluler pada tuberkulosis. Keempat, menentukan formulasi Extended Runge Kutta orde empat model imunologi seluler pada tuberkulosis. Kelima, menghitung nilai fungsi evaluasi yang terdapat pada formulasi Extended Runge Kutta orde empat model imunologi seluler pada tuberkulosis. Keenam 
menghitung solusi $M_{U_{i}}, M_{I_{i}}, B_{i}$ dan $T_{i}$ Extended Runge Kutta orde empat . Ketujuh, saat iterasi $i<5000$ maka iterasi dilanjutkan dan kembali ke langkah 5. Kemudian saat iterasi $i=5000$, maka iterasi berhenti dan diperolehlah hasil iterasi yang merupakan solusi dari model imunologi seluler pada tuberkulosis dengan metode Extended Runge Kutta orde empat. Selanjutnya menghitung nilai galat $M_{U_{i}}, M_{I_{i}}, B_{i}$ dan $T_{i}$. Setelah diperoleh solusi dan nilai galat pada metode Extended Runge Kutta orde empat, maka selanjutnya akan dilakukan perbandingan dengan metode Runge Kutta orde empat.

\section{MODEL IMUNOLOGI SELULER PADA TUBERKULOSIS}

Model imunologi seluler pada tuberkulosis pada penelitian ini terdiri dari empat variabel tak bebas yang dirumuskan sebagai berikut [4]:

$$
\left.\begin{array}{l}
\frac{d M_{U}(t)}{d t}=\mu_{U}-\mu_{U} M_{U}(t)-\beta B(t) M_{U}(t) \\
\frac{d M_{I}(t)}{d t}=\beta B(t) M_{U}(t)-\alpha_{T} M_{I}(t) T(t)-\mu_{I} M_{I}(t) \\
\frac{d B(t)}{d t}=r M_{I}(t)-\gamma_{U} M_{U}(t) B(t)-\mu_{B} B(t) \\
\frac{d T(t)}{d t}=k_{I} M_{I}(t)-k_{I} M_{I}(t) T(t)-\mu_{T} T(t)
\end{array}\right\}
$$

dengan $M_{U}(t), M_{I}(t), B(t)$, dan $T(t)$ secara berturut-turut menunjukkan populasi makrofag tak terinfeksi, populasi makrofag terinfeksi, populasi bakteri Mtb, dan populasi sel T pada saat $t$ waktu. Selanjutnya untuk paramter $\beta, \alpha_{T}, \mu_{U}, \mu_{B}, \mu_{I}, \mu_{T}, r, \gamma_{U}$ dan $k_{I}$ semuanya adalah koefisien dan konstanta positif pada Sistem Persamaan (1). Parameter $\beta$ menunjukkan laju infeksi bakteri, $\alpha_{T}$ menunjukkan laju pertumbuhan sel $\mathrm{T}$ terhadap makrofag terinfeksi, $\mu_{U}$ adalah laju kematian makrofag tak terinfeksi, $\mu_{B}$ menunjukkan laju kematian alami bakteri, $\mu_{I}$ sebagai kematian makrofag terinfeksi, $r$ adalah jumlah rata-rata produksi bakteri pada makrofag terinfeksi, $\gamma_{U}$ sebagai laju kematian bakteri terinfeksi dan $k_{I}$ adalah laju pertumbuhan sel T. Dalam penelitian ini, model imunologi seluler pada tuberkulosis diselesaikan dengan menggunakan metode Extended Runge Kutta orde empat dan Runge Kutta orde empat.

\section{METODE RUNGE KUTTA ORDE EMPAT}

Metode Runge Kutta merupakan metode numerik satu langkah yang digunakan untuk menyelesaikan persamaan diferensial dengan ketelitian dan kestabilan yang cukup tinggi. [5]. Berikut adalah bentuk umum metode Extended Runge Kutta orde empat [5]

$$
y_{i+1}=y_{i}+\frac{1}{6}\left(k_{1}+2 k_{2}+2 k_{3}+k_{4}\right)
$$

dengan,

$k_{1}=h f\left(x_{i}, y_{i}\right)$

$k_{2}=h f\left(x_{i}+\frac{1}{2} h, y_{i}+\frac{1}{2} k_{1}\right)$

$k_{3}=h f\left(x_{i}+\frac{1}{2} h, y_{i}+\frac{1}{2} k_{2}\right)$

$k_{4}=h f\left(x_{i}+h, y_{i}+k_{3}\right)$

Persamaan (2) merupakan fungsi utama dari metode Runge Kutta orde empat sedangkan $k_{1}, k_{2}, k_{3}$ dan $k_{4}$ adalah fungsi evaluasinya. 


\section{METODE EXTENDED RUNGE KUTTA ORDE EMPAT}

Metode Extended Runge Kutta merupakan perluasan dari metode Runge Kutta. Sama halnya dengan metode Runge Kutta, metode Extended Runge Kutta merupakan salah satu metode numerik yang dapat menyelesaikan permasalahan nilai awal pada persamaan diferensial biasa linear maupun nonlinear dengan tingkat ketelitian yang cukup tinggi. Metode ini digunakan untuk mendapatkan nilai pendekatan sebagai solusi dari permasalahan persamaan diferensial [2].

Berikut adalah bentuk umum dari metode Extended Runge Kutta orde empat [1]:

$$
y_{i+1}=y_{i}+h k_{11}+\frac{1}{8} h^{2} k_{12}+\frac{1}{36} h^{2} k_{32}+\frac{25}{72} h^{2} k_{42}
$$

dengan,

$k_{11}=f\left(x_{i}, y_{i}\right)$

$k_{21}=f\left(x_{i}+\frac{1}{2} h, y_{i}+\frac{1}{2} h k_{11}\right)$

$k_{31}=f\left(x_{i}+h, y_{i}+h k_{21}\right)$

$k_{12}=f^{\prime}\left(x_{i}, y_{i}\right)$

$k_{32}=f^{\prime}\left(x_{i}+h, y_{i}+h k_{21}\right)$

$k_{42}=f^{\prime}\left(x_{i}+\frac{2}{5} h, y_{i}+h\left(\frac{7}{25} k_{11}+\frac{2}{25} k_{21}+\frac{1}{25} k_{31}\right)\right)$

Persamaan (3) merupakan fungsi utama dari metode Extended Runge Kutta orde empat, sedangkan $k_{11}, k_{21}, k_{31}, k_{12}, k_{32}$, dan $k_{42}$ adalah fungsi evaluasinya.

\section{PENYELESAIAN MODEL IMUNOLOGI SELULER PADA TUBERKULOSIS DENGAN METODE EXTENDED RUNGE KUTTA ORDE EMPAT}

Penyelesaian model imunologi sluler pada tuberkulosis dengan metode Extended Runge Kutta orde empat dapat diselesaikan dengan langkah-langkah sebagai berikut:

\section{Langkah 1}

Pada penelitian ini, penyelesaian Sistem Persamaan (1) dapat diselesaikan pada iterasi $i=0$ sampai $i=5000$, dengan waktu awal $t=0$ hari sampai waktu $t=500$ hari dan ukuran langkah $h$ yang digunakan adalah 0,1 . Kemudian nilai awal yang digunakan untuk populasi makrofag tak terinfeksi $\left(M_{U}(0)\right)=0,7$, makrofag terinfeksi $\left(M_{I}(0)\right)=0,2$, bakteri Mtb $(B(0))=0,2$ dan sel $\mathrm{T}(T(0))=0$.

\section{Langkah 2}

Langkah kedua dalam penelitian ini yaitu mengidentifikasi nilai parameter Sistem Persamaan (1) yang disajikan pada Tabel 1 berikut ini:

Tabel 1. Nilai Parameter Sistem Persamaan (1) [4]

\begin{tabular}{|c|l|c|c|}
\hline $\begin{array}{c}\text { Variabel/ } \\
\text { Parameter }\end{array}$ & \multicolumn{1}{|c|}{ Deskripsi } & Nilai Parameter & Satuan \\
\hline$\alpha_{T}$ & Laju pertumbuhan sel T terhadap makrofag terinfeksi & 0,1 & Perhari \\
\hline$\mu_{U}$ & Laju kematian alami makrofag tak terinfeksi & 0,00033 & Perhari \\
\hline$\beta$ & Laju infeksi bakteri & $8,25 \times 10^{-9}$ & Perhari \\
\hline$\mu_{I}$ & Laju kematian alami makrofag terinfeksi & 0,011 & Perhari \\
\hline$\mu_{B}$ & Laju kematian alami bakteri & 0,012 & Perhari \\
\hline$\mu_{T}$ & Laju kematian alami sel T & 0,33 & Perhari \\
\hline$r$ & $\begin{array}{l}\text { Jumlah rata-rata produksi bakteri pada makrofag } \\
\text { terinfeksi }\end{array}$ & $5 \times 0,011$ & Perhari \\
\hline$\gamma_{U}$ & Laju kematian bakteri karena makrofag terinfeksi & 0,879 & Perhari \\
\hline$k_{I}$ & Laju pertumbuhan sel T & 0,484848 & Perhari \\
\hline
\end{tabular}




\section{Langkah 3}

Selanjutnya yaitu memformulasikan model imunologi seluler pada tuberkulosis ke dalam metode Extended Runge Kutta orde empat. Sebelum memformulasikan model imunologi seluler pada tuberkulosis ke Persamaan (3), maka terlebih dahulu dicari $f\left(t, M_{U}, M_{I}, B, T\right), g\left(t, M_{U}, M_{I}, B, T\right)$, $j\left(t, M_{U}, M_{I}, B, T\right), \quad k\left(t, M_{U}, M_{I}, B, T\right), f^{\prime}\left(t, M_{U}, M_{I}, B, T\right), g^{\prime}\left(t, M_{U}, M_{I}, B, T\right), j^{\prime}\left(t, M_{U}, M_{I}, B, T\right)$ dan $k^{\prime}\left(t, M_{U}, M_{I}, B, T\right)$. Berdasarkan nilai parameter pada Langkah 2, maka Sistem Persamaan (1) dapat ditulis menjadi:

$$
\left.\begin{array}{l}
f\left(t, M_{U}, M_{I}, B, T\right)=\frac{d M_{U}(t)}{d t}=0,00033-0,00033 M_{U}(t)-8,25 \times 10^{-9} B(t) M_{U}(t) \\
g\left(t, M_{U}, M_{I}, B, T\right)=\frac{d M_{I}(t)}{d t}=8,25 \times 10^{-9} B(t) M_{U}(t)-0,1 M_{I}(t) T(t)-0,011 M_{I}(t) \\
j\left(t, M_{U}, M_{I}, B, T\right)=\frac{d B(t)}{d t}=5 \times 0,011 M_{I}(t)-0,879 M_{U}(t) B(t)-0,012 B(t) \\
k\left(t, M_{U}, M_{I}, B, T\right)=\frac{d T(t)}{d t}=0,484848 M_{I}(t)-0,484848 M_{I}(t) T(t)-0,33 T(t) \\
f^{\prime}\left(t, M_{U}, M_{I}, B, T\right)=\frac{d}{d t} \frac{d M_{U}(t)}{d t}=\left(\frac{d}{d t}\right)\left(0,00033-0,00033 M_{U}(t)-8,25 \times 10^{-9} B(t) M_{U}(t)\right) \\
g^{\prime}\left(t, M_{U}, M_{I}, B, T\right)=\frac{d}{d t} \frac{d M_{I}(t)}{d t}=\left(\frac{d}{d t}\right)\left(8,25 \times 10^{-9} B(t) M_{U}(t)-0,1 M_{I}(t) T(t)-0,011 M_{I}(t)\right) \\
j^{\prime}\left(t, M_{U}, M_{I}, B, T\right)=\frac{d}{d t} \frac{d B(t)}{d t}=\left(\frac{d}{d t}\right)\left(5 \times 0,011 M_{I}(t)-0,879 M_{U}(t) B(t)-0,012 B(t)\right) \\
k^{\prime}\left(t, M_{U}, M_{I}, B, T\right)=\frac{d}{d t} \frac{d T(t)}{d t}=\left(\frac{d}{d t}\right)\left(0,484848 M_{I}(t)-0,484848 M_{I}(t) T(t)-0,33 T(t)\right)
\end{array}\right\}
$$

\section{Langkah 4}

Setelah diperoleh fungsi-fungsi pada Langkah 3, maka langkah selanjutnya memformulasikan fungsifungsi yang terdapat pada Sistem Persamaan (4) ke dalam metode Extended Runge Kutta orde empat. Pada Persamaan (3). Dengan ukuran langkah $h$ yang telah ditentukan pada Langkah 1, maka diperoleh formulasi sebagai berikut:

$$
\left.\begin{array}{l}
M_{U_{(i+1)}}=M_{U_{i}}+0,1 l_{11}+0,1^{2} \frac{1}{8} l_{12}+0,1^{2} \frac{1}{36} l_{32}+0,1^{2} \frac{25}{72} l_{42} \\
M_{I_{(i+1)}}=M_{I_{i}}+0,1 m_{11}+0,1^{2} \frac{1}{8} m_{12}+0,1^{2} \frac{1}{36} m_{32}+0,1^{2} \frac{25}{72} m_{42} \\
B_{i+1}=B_{i}+0,1 p_{11}+0,1^{2} \frac{1}{8} p_{12}+0,1^{2} \frac{1}{36} p_{32}+0,1^{2} \frac{25}{72} p_{42} \\
T_{i+1}=T_{0}+0,1 q_{11}+0,1^{2} \frac{1}{8} q_{12}+0,1^{2} \frac{1}{36} q_{32}+0,1^{2} \frac{25}{72} q_{42}
\end{array}\right\}
$$

\section{Langkah 5}

Fungsi evaluasi metode Extended Runge Kutta orde empat untuk model imunologi seluler pada tuberkulosis yang terdapat pada Sistem Persamaan (5), yaitu $l_{11}, l_{12}, l_{32}, l_{42}, m_{11}, m_{12}, m_{32}, m_{42}, p_{11}$, $p_{12}, p_{32}, p_{42}, q_{11}, q_{12}, q_{32}$ dan $q_{42}$. Nilai-nilai fungsi evaluasi pada Sistem Persamaan (5) dapat dihitung dengan menggunakan rumus fungsi evaluasi metode Extended Runge Kutta orde empat pada Persamaan (3). Untuk iterasi pertama dengan $i=0$ dan waktu $t=0$, maka nilai setiap fungsi evaluasi tersebut dapat dilihat pada Tabel 2 berikut ini, dengan $n=1,2,3$, dan 4 . 
Tabel 2. Nilai Fungsi Evaluasi Persamaan (5)

\begin{tabular}{|c|c|c|c|c|}
\hline \multirow{2}{*}{ Variabel } & \multicolumn{4}{|c|}{ Nilai Fungsi Evaluasi } \\
\cline { 2 - 5 } & $n=1$ & $n=2$ & $n=3$ & $n=4$ \\
\hline$l_{n 1}$ & 0,000099000 & - & - & - \\
\hline$m_{n 1}$ & $-0,002200000$ & - & - & - \\
\hline$p_{n 1}$ & 0,011000000 & - & - & - \\
\hline$q_{n 1}$ & 0,096969000 & - & - & $-3,27315 \times 10^{-8}$ \\
\hline$l_{n 2}$ & $-3,27335 \times 10^{-8}$ & - & $-3,27285 \times 10^{-8}$ & $-0,001878929$ \\
\hline$m_{n 2}$ & $-0,001915192$ & - & $-0,001825543$ & $-0,006726360$ \\
\hline$p_{n 2}$ & $-0,006892930$ & - & $-0,006484370$ & $-0,041778707$ \\
\hline$q_{n 2}$ & $-0,042469737$ & - & $-0,040762920$ & \\
\hline
\end{tabular}

\section{Langkah 6}

Setelah melakukan perhitungan pada Langkah 5, diperoleh nilai-nilai fungsi evaluasi seperti yang disajikan pada Tabel 2. Kemudian setiap nilai fungsi evaluasi yang diperoleh pada Tabel 2 disubstitusikan ke Sistem Persamaan (5). Maka solusi numerik model imunologi seluler pada tuberkulosis dengan metode Extended Runge Kutta orde empat untuk iterasi pertama yaitu $i=0$ dengan waktu $t=0$ adalah sebagai berikut:

$$
\begin{aligned}
M_{U_{1}} & =0,7+0,1(0,000099)+0,1^{2} \frac{1}{8}\left(-3,27335 \times 10^{-8}\right)+0,1^{2} \frac{1}{36}\left(-3,27285 \times 10^{-8}\right)+0,1^{2} \frac{25}{72}\left(-3,2732 \times 10^{-8}\right) \\
& =0,7000099 \\
M_{I_{1}} & =0,2+0,1(-0,0022)+0,1^{2} \frac{1}{8}(-0,001915192)+0,1^{2} \frac{1}{36}(-0,001825543)+0,1^{2} \frac{25}{72}(-0,001878929) \\
& =0,199770575 \\
B_{1}= & 0+0,1(0,011)+0,1^{2} \frac{1}{8}(-0,00689293)+0,1^{2} \frac{1}{36}(-0,00648437)+0,1^{2} \frac{25}{72}(-0,00672636) \\
\quad & 0,001066227 \\
T_{1}= & T_{0}+0,1(0,096969)+0,1^{2} \frac{1}{8}(-0,042469737)+0,1^{2} \frac{1}{36}(-0,04076292)+0,1^{2} \frac{25}{72}(-0,041778707) \\
= & 0,009487485 .
\end{aligned}
$$

Berdasarkan hasil perhitungan pada Langkah 6, diperoleh solusi numerik model imunologi seluler pada tuberkulosis dengan metode Extended Runge Kutta orde empat. Dengan empat variabel tak bebas yang terdiri dari variabel populasi makrofag tak terinfeksi $\left(M_{U}\right)$, variabel populasi makrofag terinfeksi $\left(M_{I}\right)$, variabel populasi bakteri Mtb $(B)$, dan variabel populasi sel $\mathrm{T}(T)$. Untuk perhitungan solusi numerik pada iterasi pertama dengan $i=0$ saat waktu $t=0$ diperoleh solusi numerik keempat variabel tersebut secara berturut-turut, yaitu $M_{U_{1}}=0,7000099 \mathrm{sel} / \mathrm{ml}, M_{I_{1}}=0,199770575 \mathrm{sel} / \mathrm{ml}$, $B_{1}=0,001066227 \mathrm{sel} / \mathrm{ml}$ dan $T_{1}=0,009487485 \mathrm{sel} / \mathrm{ml}$. Kemudian dengan cara yang sama, untuk perhitungan solusi iterasi ke dua $i=1$ model imunologi seluler pada tuberkulosis dengan metode Extended Runge Kutta orde empat saat $t=0,1$ sampai iterasi $i=5000$ saat $t=500$ hari, perhitungan dilakukan menggunakan bantuan program Excel, sehingga diperoleh nilai pada Tabel 3 sebagai berikut: 
Tabel 3. Solusi $M_{U}(t), M_{I}(t), B(t)$, dan $T(t)$ dengan Metode ERK4

\begin{tabular}{|c|c|c|c|c|c|}
\hline \multirow{2}{*}{$i$} & \multirow{2}{*}{$\begin{array}{c}t \\
\text { (hari) }\end{array}$} & $M_{U_{(i+1)}}$ & $M_{I_{(i+1)}}$ & $B_{i+1}$ & $T_{i+1}$ \\
\hline 1 & 0,1 & 0,700009900 & 0,199770575 & 0,001066227 & 0,009487485 \\
\hline 2 & 0,2 & 0,700019799 & 0,199522892 & 0,002066311 & 0,018567290 \\
\hline 3 & 0,3 & 0,700029699 & 0,199257815 & 0,003004180 & 0,027255828 \\
\hline 4 & 0,4 & 0,700039597 & 0,198976178 & 0,003883525 & 0,035568874 \\
\hline 5 & 0,5 & 0,700049496 & 0,198678783 & 0,004707821 & 0,043521587 \\
\hline 6 & 0,6 & 0,700059394 & 0,198366401 & 0,005480334 & 0,051128532 \\
\hline 7 & 0,7 & 0,700069292 & 0,198039776 & 0,006204134 & 0,058403702 \\
\hline 8 & 0,8 & 0,700079190 & 0,197699622 & 0,006882111 & 0,065360541 \\
\hline 9 & 0,9 & 0,700089087 & 0,197346626 & 0,007516981 & 0,072011960 \\
\hline 10 & 1 & 0,700098984 & 0,196981449 & 0,008111299 & 0,078370360 \\
\hline 50 & 5 & 0,700494592 & 0,177460813 & 0,015465970 & 0,188618380 \\
\hline 70 & 7 & 0,700692200 & 0,167014982 & 0,015127022 & 0,195728203 \\
\hline 100 & 10 & 0,700988368 & 0,152453358 & 0,013990721 & 0,190669612 \\
\hline 1000 & 100 & 0,709738428 & 0,025517749 & 0,002260493 & 0,037718349 \\
\hline 5000 & 500 & 0,745631885 & 0,000233123 & 0,0000195374 & 0,000354234 \\
\hline
\end{tabular}

Hasil perhitungan yang diperoleh pada Tabel 3 dengan nilai awal yang telah ditentukan dan nilai parameter yang terdapat pada Tabel 1 terlihat bahwa populasi makrofag tak terinfeksi $\left(M_{U}\right)$ mengalami peningkatan dari waktu ke-0,1 sampai ke-500 hari yang mencapai $0,745631885 \mathrm{sel} / \mathrm{ml}$. Pertumbuhan populasi makrofag terinfeksi $\left(M_{I}\right)$ mengalami penurunan dari waktu ke-0,1 sampai ke500 hari yang mencapai $0,000233123 \mathrm{sel} / \mathrm{ml}$. Populasi bakteri $M t b(B)$ mengalami peningkatan dari waktu ke-0,1 hingga ke-5 hari yang mencapai $0,01546597 \mathrm{sel} / \mathrm{ml}$, namun setelah itu populasi bakteri mengalami penurunan hingga waktu ke-500 hari yang mencapai $0,0000195374 \mathrm{sel} / \mathrm{ml}$. Kemudian untuk sel T $(T)$ mengalami peningkatan dari waktu ke-0,1 hingga ke-7 hari sebesar 0,195771015 $\mathrm{sel} / \mathrm{ml}$ dan setelah itu mengalami penurunan hingga waktu ke-500 hari yaitu mencapai 0,000354234 $\mathrm{sel} / \mathrm{ml}$. Berdasarkan solusi yang diperoleh pada Tabel 3, maka bentuk grafik dapat dilihat seperti pada Gambar 1 sebagai berikut:

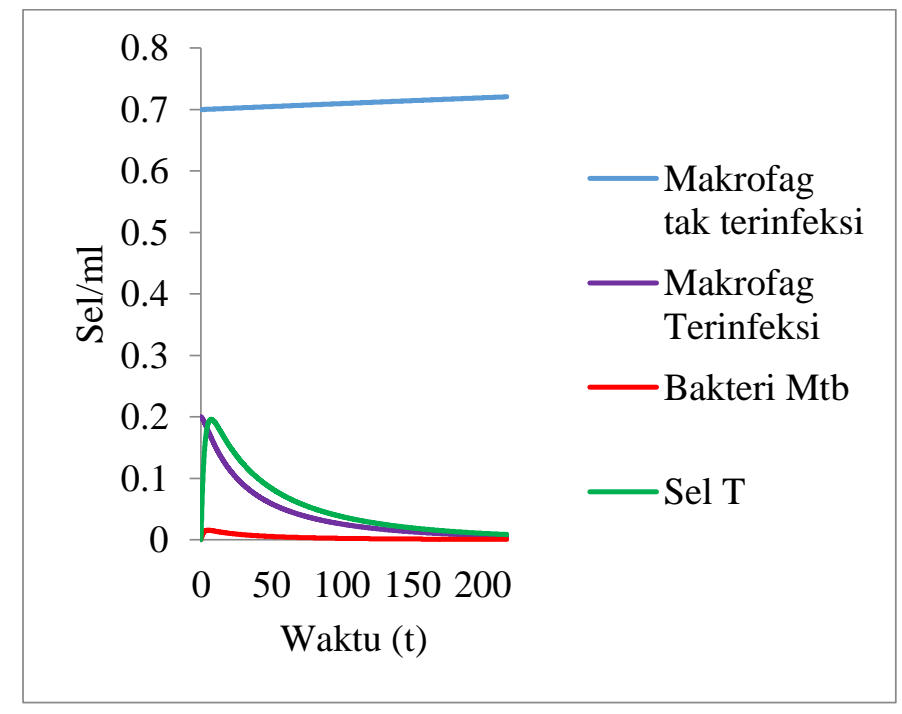

Gambar 1. Grafik Solusi dengan Metode ERK4 
Gambar 1 menunjukkan bahwa makrofag tak terinfeksi $\left(M_{U}\right)$ terus mengalami peningkatan dari $t=0,1$ hari hingga waktu $t=500$ hari. makrofag terinfeksi $\left(M_{I}\right)$ terus mengalami penurunan dari waktu $t=0,1$ hari hingga waktu $t=500$ hari. Sedangkan untuk bakteri $M t b(B)$ dan sel T ( $T$ ) mengalami peningkatan pada waktu tertentu yang kemudian setelah itu mengalami penurunan lagi hingga waktu ke-500 hari.

\section{SOLUSI MODEL IMUNOLOGI SELULER PADA TUBERKULOSIS DENGAN METODE RUNGE KUTTA ORDE EMPAT}

Penyelesaian model imunologi seluler pada tuberkulosis dengan metode Runge Kutta orde empat dapat diselesaikan dengan cara yang sama seperti pada metode Extended Runge Kutta orde empat. Berikut ini adalah tabel solusi model imunologi seluler pada tuberkulosis dengan menggunakan metode Runge Kutta orde empat dapat dilihat pada Tabel 4:

Tabel 4. Solusi $M_{U}(t), M_{I}(t), B(t)$, dan $T(t)$ dengan Metode RK4

\begin{tabular}{|c|c|c|c|c|c|}
\hline \multirow{2}{*}{$i$} & \multirow{2}{*}{$\begin{array}{c}t \\
\text { (hari) }\end{array}$} & \multicolumn{4}{|c|}{ Variabel } \\
\hline & & $M_{U_{(i+1)}}$ & $M_{I_{(i+1)}}$ & $B_{i+1}$ & $T_{i+1}$ \\
\hline 0 & 0 & 0,7 & 0,2 & 0 & 0 \\
\hline 1 & 0,1 & 0,700009900 & 0,199770575 & 0,001065599 & 0,009487485 \\
\hline 2 & 0,2 & 0,700019799 & 0,199522892 & 0,002065131 & 0,018567290 \\
\hline 3 & 0,3 & 0,700029699 & 0,199257815 & 0,003002519 & 0,027255828 \\
\hline 4 & 0,4 & 0,700039597 & 0,198976178 & 0,003881447 & 0,035568873 \\
\hline 5 & 0,5 & 0,700049496 & 0,198678783 & 0,004705383 & 0,043521586 \\
\hline 6 & 0,6 & 0,700059394 & 0,198366401 & 0,005477589 & 0,051128531 \\
\hline 7 & 0,7 & 0,700069292 & 0,198039776 & 0,006201129 & 0,058403701 \\
\hline 8 & 0,8 & 0,700079190 & 0,197699622 & 0,006878889 & 0,065360540 \\
\hline 9 & 0,9 & 0,700089087 & 0,197346626 & 0,007513580 & 0,072011958 \\
\hline 10 & 1 & 0,700098984 & 0,196981449 & 0,008107755 & 0,078370358 \\
\hline 50 & 5 & 0,700494592 & 0,177460813 & 0,015464842 & 0,188618379 \\
\hline 70 & 7 & 0,700692200 & 0,167014982 & 0,015126839 & 0,195728203 \\
\hline 100 & 10 & 0,700988368 & 0,152453358 & 0,013991010 & 0,190669612 \\
\hline 1000 & 100 & 0,709738428 & 0,025517749 & 0,002260526 & 0,037718349 \\
\hline 5000 & 500 & 0,745631885 & 0,000233123 & 0,0000195376 & 0,000354234 \\
\hline
\end{tabular}

Hasil perhitungan yang diperoleh pada Tabel 4 dengan parameter dan nilai awal yang telah ditentukan pada Tabel 1 terlihat bahwa populasi makrofag tak terinfeksi $\left(M_{U}\right)$ mengalami peningkatan dari waktu ke-0,1 sampai ke-500 hari yang mencapai $0,745631885 \mathrm{sel} / \mathrm{ml}$. Pertumbuhan populasi makrofag terinfeksi $\left(M_{I}\right)$ mengalami penurunan dari waktu ke-0,1 sampai ke-500 hari yang mencapai $0,000233123 \mathrm{sel} / \mathrm{ml}$. Populasi bakteri Mtb $(B)$ mengalami peningkatan dari waktu ke-0,1 hingga ke-5 hari yang mencapai $0,015464842 \mathrm{sel} / \mathrm{ml}$, namun setelah itu populasi bakteri mengalami penurunan hingga waktu ke-500 hari yang mencapai $1,95376 \times 10^{-5} \mathrm{sel} / \mathrm{ml}$. Kemudian untuk sel T $(T)$ mengalami peningkatan dari waktu ke-0,1 hingga ke-7 hari sebesar 0,195728203 sel/ml dan setelah itu mengalami penurunan hingga waktu ke-500 hari yaitu mencapai 0,000354234 sel/ml. Berdasarkan solusi yang diperoleh pada Tabel 4, maka bentuk grafik solusi dapat dilihat seperti pada Gambar 2 sebagai berikut: 


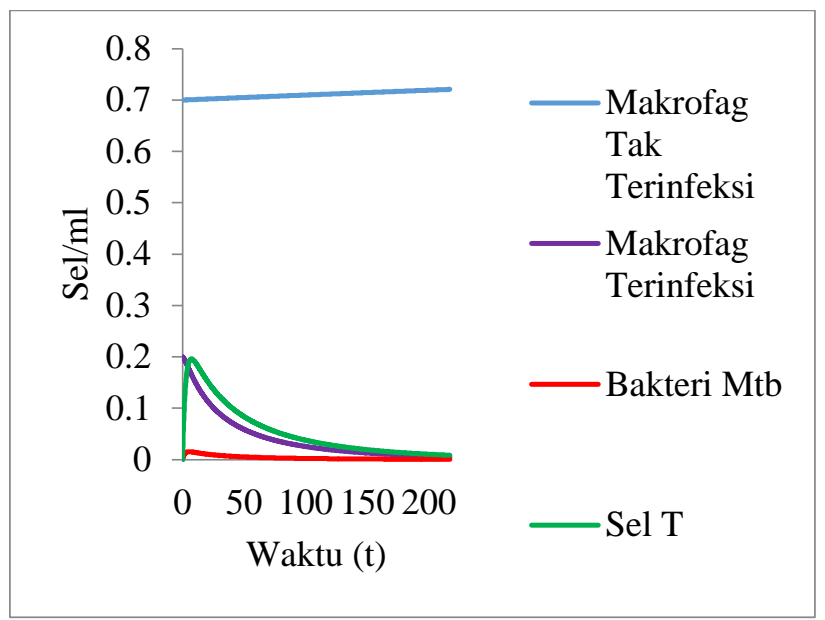

\section{Gambar 2. Gafik Solusi dengan Metode RK4}

Gambar 2 menunjukkan bahwa makrofag tak terinfeksi $\left(M_{U}\right)$ terus mengalami peningkatan dari waktu $t=0,1$ hari hingga waktu ke-500 hari. Makrofag terinfeksi $\left(M_{I}\right)$ terus mengalami penurunan dari waktu ke 0,1 hingga waktu ke-500 hari. Sedangkan untuk bakteri Mtb (B) dan Sel T (T) mengalami peningkatan pada waktu tertentu, setelah itu mengalami penurunan lagi hingga waktu ke-500 hari.

\section{ANALISIS GALAT METODE EXTENDED RUNGE KUTTA ORDE EMPAT DAN RUNGE KUTTA ORDE EMPAT}

Galat yang digunakan dalam penelitian ini adalah galat perlangkah. Galat perlangkah pada metode Extended Runge Kutta orde empat dan Runge Kutta orde empat dapat dirumuskan sebagai berikut: [6]

$$
\varepsilon_{M_{U}}=\left|M_{U_{i}}-M_{U_{(i+1)}}\right|, \varepsilon_{M_{I}}=\left|M_{I_{i}}-M_{I_{(i+1)}}\right|, \varepsilon_{B}=\left|B_{i}-B_{i+1}\right| \text {, dan } \varepsilon_{T}=\left|T_{i}-T_{i+1}\right| \text {. }
$$

Hasil perhitungan galat model imunologi seluler pada tuberkulosis dengan metode Extended Runge Kutta orde empat dan Runge Kutta orde empat dapat dilihat pada Tabel 5 berikut ini:

Tabel 5. Nilai Galat Metode ERK4 dan RK4

\begin{tabular}{|c|c|c|c|c|}
\hline \multirow{2}{*}{$i$} & \multirow{2}{*}{$t$ (hari) } & \multirow{2}{*}{ Variabel } & \multicolumn{2}{|c|}{ Nilai Galat } \\
\hline & & & RK4 & ERK4 \\
\hline \multirow{4}{*}{1} & \multirow{4}{*}{0,1} & $M_{\left.U_{(i+1}\right)}$ & $9,899840 \times 10^{-6}$ & $9,899840 \times 10^{-6}$ \\
\hline & & $M_{I_{(i+1)}}$ & $2,294250 \times 10^{-4}$ & $2,294250 \times 10^{-4}$ \\
\hline & & $B_{i+1}$ & $1,065599 \times 10^{-3}$ & $1,066227 \times 10^{-3}$ \\
\hline & & $T_{i+1}$ & $9,487485 \times 10^{-3}$ & $9,487485 \times 10^{-3}$ \\
\hline \multirow{4}{*}{100} & \multirow{4}{*}{10} & $M_{U_{(i+1)}}$ & $9,867540 \times 10^{-6}$ & $9,867540 \times 10^{-6}$ \\
\hline & & $M_{I_{(i+1)}}$ & $4,593060 \times 10^{-4}$ & $4,593060 \times 10^{-4}$ \\
\hline & & $B_{i+1}$ & $4,037800 \times 10^{-5}$ & $4,038430 \times 10^{-5}$ \\
\hline & & $T_{i+1}$ & $3,070100 \times 10^{-4}$ & $3,070100 \times 10^{-4}$ \\
\hline \multirow{4}{*}{1000} & \multirow{4}{*}{100} & $M_{U_{(i+1)}}$ & $9,578790 \times 10^{-6}$ & $9,578790 \times 10^{-6}$ \\
\hline & & $M_{I_{(i+1)}}$ & $3,772920 \times 10^{-5}$ & $3,772920 \times 10^{-5}$ \\
\hline & & $B_{i+1}$ & $3,393370 \times 10^{-6}$ & $3,393310 \times 10^{-6}$ \\
\hline & & $T_{i+1}$ & $5,419620 \times 10^{-5}$ & $5,419620 \times 10^{-5}$ \\
\hline \multirow{4}{*}{5000} & \multirow{4}{*}{500} & $M_{U_{(i+1)}}$ & $8,394290 \times 10^{-6}$ & $8,394290 \times 10^{-6}$ \\
\hline & & $M_{I_{(i+1)}}$ & $2,574030 \times 10^{-7}$ & $2,574030 \times 10^{-6}$ \\
\hline & & $B_{i+1}$ & $2,179370 \times 10^{-8}$ & $2,179350 \times 10^{-8}$ \\
\hline & & $T_{i+1}$ & $3,910300 \times 10^{-7}$ & $3,910300 \times 10^{-7}$ \\
\hline
\end{tabular}


Tabel 5 menunjukkan bahwa tidak ada perbedaan galat yang signifikan. Terdapat kesamaan nilai galat metode Extended Runge Kutta orde empat dang Runge Kutta orde empat pada tiga variabel, yaitu variabel makrofag tak terinfeksi, makrofag terinfeksi, dan sel T. Namun, dalam hal ini terdapat perbedaan nilai galat pada variabel bakteri $M t b(B)$. Pada saat iterasi pertama dengan $i=1$ dan waktu $t=0,1$ hari, terlihat bahwa nilai galat metode Runge Kutta orde empat lebih kecil dari metode Extended Runge Kutta orde empat hingga iterasi ke 16 saat waktu 1,6 hari. Namun untuk iterasi selanjutnya sampai iterasi ke 5000 dengan waktu $t=500$ hari terdapat perubahan nilai galat pada metode Extended Runge Kutta orde empat, yaitu diperoleh nilai galat bakteri Mtb (B) metode Extended Runge Kutta orde empat lebih kecil dari galat bakteri Mtb $(B)$ Runge Kutta orde empat. Berdasarkan Tabel 5, berikut dapat dilihat perbandingan nilai galat untuk variabel bakteri Mtb $(B)$ metode Extended Runge Kutta orde empat dan metode Runge Kutta orde empat pada Gambar 3.

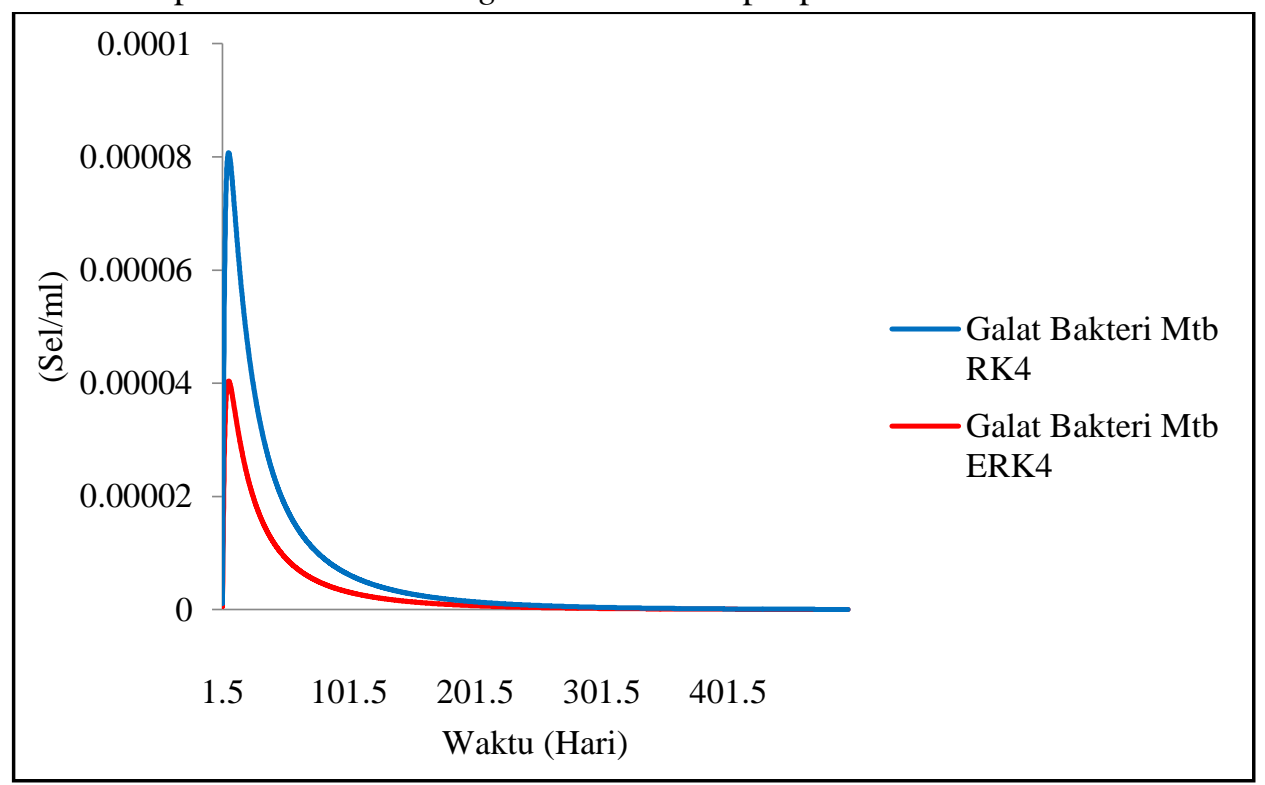

Gambar 3. Grafik Perbandingan Nilai Galat Variabel Bakteri Metode ERK4 dan RK4

Garis biru menggambarkan nilai galat untuk variabel bakteri Mtb (B) pada metode Runge Kutta orde empat, sedangkan garis merah menggambarkan nilai galat untuk variabel bakteri Mtb $(B)$ metode Extended Runge Kutta orde empat. Berdasarkan Gambar 3, Pada saat iterasi pertama dengan $i=1$ dan waktu $t=0,1$ hari, terlihat bahwa nilai galat metode Runge Kutta orde empat lebih kecil dari metode Extended Runge Kutta orde empat hingga iterasi ke 16 saat waktu 1,6 hari. Namun untuk iterasi selanjutnya sampai iterasi ke 5000 dengan waktu $t=500$ hari terdapat perubahan nilai galat pada metode Extended Runge Kutta orde empat, yaitu diperoleh nilai galat bakteri Mtb (B) metode Extended Runge Kutta orde empat lebih kecil dari galat bakteri Mtb (B) Runge Kutta orde empat.

\section{PENUTUP}

Penyelesaian solusi numerik yang dihasilkan oleh metode Extended Runge kutta orde empat dan metode Runge Kutta orde empat tidak terdapat perbedaan yang signifikan. Terdapat kesamaan nilai solusi dan nilai galat yang diperoleh pada variabel makrofag tak terinfeksi $\left(M_{U}\right)$, makrofag terinfeksi $\left(M_{i}\right)$, dan Sel $T(T)$. Ada perbedaan nilai solusi dan nilai galat yang diperoleh pada variabel bakteri Mtb (B) metode Extended Runge Kutta orde empat dan Runge Kutta orde empat. Pada saat iterasi pertama dengan $i=1$ dan waktu $t=0,1$ hari nilai solusi dan nilai galat metode Runge Kutta orde empat lebih kecil dari Extended Runge Kutta orde empat hingga iterasi ke 16 saat waktu 1,6 hari. Namun untuk iterasi selanjutnya sampai iterasi ke 5000 dengan waktu $t=500$ hari diperoleh nilai solusi dan nilai galat bakteri Mtb $(B)$ metode Extended Runge Kutta orde empat lebih kecil Runge Kutta orde empat. 


\section{DAFTAR PUSTAKA}

[1] Muhammad ST. Pengkajian Metode Extended Runge Kutta dan Penerapannya pada Persamaan Diferensial Biasa. Jurnal Sains dan Seni. 2015; 4: 25-30.

[2] Wu X dan Jianlin X. Extended Runge-Kutta-Like formulae. Appliied Numerical Mathematic. 2006, 56:1584-1605.

[3] Jikantoro YD, Fudziah I, Norazak S, dan Muhammed S. Improved Extended Runge -Kutta-like Method for Solving Firs Order IVPs. Indian Journal of Science and Technology. 2016; ISSN: 0974-5645.

[4] Mondragon EI, Lourdes E, Leslie CG. A Mathematical Model for Cellular Immunology of Tuberculosis. Mathematical Biosciences and Enginering. 2015, 8: 973-986.

[5] Sasongko SB. Metode Numerik dengan scilab. Yogyakarta; CV. ANDI OFFSET; 2010.

[6] Munir R. Metode Numerik. Bandung; Informatika Bandung; 2015.

RIA RISCA PRATIWI : Jurusan Matematika FMIPA UNTAN, Pontianak, riariscapratiwi.49@gmail.com

HELMI : Jurusan Matematika FMIPA UNTAN, Pontianak, helmi132205@yahoo.co.id

YUDHI : Jurusan Matematika FMIPA UNTAN, Pontianak, yudhi@math.untan.ac.id 